\title{
Un Oscar sin glamour: "The Cove”
}

La noche de los Oscar, en su 82a edición, se siguió con gran interés -un interés creciente, por cierto- en España, quizá por figurar este año como candidatos a los premios algunos españoles. En marzo empieza a ser una cita obligada, no sólo para los cinéfilos, la larga noche de seguimiento de la concesión de los premios más prestigiosos del mundo del cine. La diferencia horaria con Los Angeles, hace que sólo los más noctámbulos resistan la retransmisión completa de la velada. Los que no resisten, buscan la información al día siguiente en las primeras páginas de los periódicos o en los boletines de noticias de la radio. Este año, me sorprendió gratamente la noticia de la concesión del Oscar al mejor documental, a una película que había tenido ocasión de ver en el mes de agosto en un cine de New York, en pleno corazón del Village. Sin embargo, la mención del documental premiado pasó inadvertido para la gran mayoría de los aficionados al cine, incluso para los que se consideran animalistas. Un premio, que por no tener rasgos de glamour, ha sido penosamente silenciado.

El documental oscarizado este año se titula “The Cove” (http://www.thecovemovie.com), un thriller impresionante contra la anual matanza de delfines (más de 23.000, cada año), que se lleva a cabo en Japón, en el Parque Nacional de Taiji, en Wakayama, de forma sistemática, a pesar de las crecientes protestas de las Asociaciones proteccionistas y ecologistas y de los simples particulares, que no pueden entender semejante barbarie.

La “pequeña historia” de la película empezó el día en que Ric O’Barry, el famoso entrenador de los delfines -cinco en total-, que en los años 60 rodaron la serie "Flipper", asistiera a la muerte voluntaria en sus brazos (una especie de suicidio), de uno de los cetáceos que había entrenado para la película. "Flipper”, sin duda, contribuyó a hacer del delfín una especie marina querida y admirada por los niños de todo el mundo, que acuden a verlos actuar a los delfinarios, sin advertir, claro está, cúanto estrés y angustia hay detrás de sus acrobacias, pues ellos, hechos para nadar en la inmensidad del océano, tienen que vivir confinados en piscinas reducidas y a hacer doblete, sobre todo en los meses de buen tiempo, para diversión de familias y de turistas. A partir de aquel hecho, Ric O’Barry decidió dedicar sus esfuerzos a acabar con esa forma de abuso de los delfines y ello le puso en contacto con una realidad aún más dura y violenta, que, por estar cuidadosamente oculta, no pudo sospechar cuando era entrenador de delfines y acudía al parque de Taiji, una localidad mundialmente conocida por los espectáculos descritos, pero, hoy en día, conocida también por haber tratado de preservar en secreto la matanza cruenta que "The Cove", pone al descubierto.

La película fue rodada por un equipo dirigido por el conocido fotógrafo de "National Geographic” Louie Psihoyos, con la colaboración de Ric O’Obarry y un equipo que no dudó en arriesgarse hasta el límite, para superar las trabas y el rechazo que los habitantes de Taiji, ponen en marcha para evitar que las imágenes cruentas de la matanza se conozcan. El documental es un revulsivo para cualquiera que, con un mínimo de sensibilidad, vea las aguas teñidas de un rojo intenso, de la sangre que derraman los delfines que, en dicha zona de Japón, nadan libre e inocentemente por los alrededores y son arponeados por los pescadores de Taijí, cuando los atraen a una cueva (“The Cove”) del litoral, oculta a las miradas, mediante ruidos realizados con objetos metálicos, que confunde y aturde a los delfines. Una vez allí, les cierran la salida con unas redes y, desde pequeñas barcas -a pie incluso-, por estar en la orilla, los matan entre gritos. La sensación, cuando se sale de la sala de proyección, es de vacío y de impotencia. Al rato, la indignación por la crueldad de la masacre, sustituye a dichos sentimientos. 
No hace falta recordar algo que es bien sabido, la inteligencia, la afinidad de los delfines con los humanos, su capacidad de aprendizaje y de empatía. No hace falta recordar que es una especie que está siendo sistemáticamente extinguida, que con ello se está privando a nuestras aguas de una riqueza que debería de ser respetada. No hace falta recordar que se miran con indiferencia -está tan lejos...!- las matanzas masivas de especies (focas, por ejemplo) que algunos países sistemáticamente practican. No hace falta recordar, que la legislación, abundantísima, para la protección de la biodiversidad se ignora por los países que sacan provecho de la explotación animal. No hacía falta recordarlo, pero se agradece, y de verdad, que el talento de la industria cinematográfica se ponga al servicio de una causa noble como ésta. No dejen de ver la película, aunque carezca de glamour!.

LA EDITORA

Teresa Giménez-Candela Catedrática de Derecho Romano Directora del Master en Derecho Animal y Sociedad

Directora del ICALP

Universitat Autònoma de Barcelona

Sígueme en Facebook: https://www.facebook.com/editora.da 